\title{
OPTIMIZATION OF EXTRUSION PROCESS FOR PRODUCTION OF TEXTURIZED FLAXSEED DEFATTED MEAL BY RESPONSE SURFACE METHODOLOGY
}

\author{
Suresh Bhise ${ }^{1}$, Kaur $A^{2}$, Manikantan $M R^{3}$, Baljit Singh ${ }^{4}$ \\ ${ }^{1,2,4}$ Department of Food Science and Technology, Punjab Agricultural University, Ludhiana, Punjab, India \\ ${ }^{3}$ Food Grain and Oilseeds Division, CIPHET, Ludhiana, India, sureshbhise_cft@yahoo.co.in ${ }^{1}$
}

\begin{abstract}
The objective of this work was to obtain and evaluate the nutritional and functional properties of texturized defatted flaxseed meal rich in protein. The flaxseed was defatted, grinded, and sieved to eliminate hull fiber. The independent variables used were 14 to 20 per cent feed moisture; 300 to $500 \mathrm{rpm}$ screw speed and 120 to $180^{\circ} \mathrm{C}$ barrel temperature. The texturized flaxseed defatted meal contained 2.61per cent moisture, 2.707 per cent fat, 38.24 per cent protein and 12.24 per cent fiber. During texturization two important reactions (protein denaturation and starch gelatinization) in dough can affect viscosity. Functional properties as indicated by this study, texturized defatted flaxseed meal may be recommended for use as an ingredient in products such as noodles, cookies, extruded snacks, meat batters, hamburgers, and ice cream.
\end{abstract}

Keywords: Extrusion, Flaxseed meal, Texturization, Response surface methodology etc.

\section{INTRODUCTION}

Extrusion technology is extensively used for preparation of new protein sources, such as oilseeds, leguminous seeds, leaf and single cell proteins [1]. Providing safe, nutritious, and wholesome food for poor and undernourished populations had been a major challenge for the developing world [2,3]. It had been estimated that 800 million malnourished people exist in least developed countries. Development of nutritious foods has been suggested by FAO to combat malnutrition among children for maintaining good health. Animal proteins are a better source of high quality proteins than vegetable proteins [4]. However, animal protein foods are more expensive than vegetable protein [5]. Due to the price and relative scarcity of food obtained from animals, it is necessary to find or develop new alternative products that offer both better quality and a greater quantity of proteins.

Flaxseed has been consumed throughout the world for centuries. Today, flaxseed is used as a good source of soluble and insoluble fiber to reduce blood cholesterol and promote laxation [6]. However, flaxseed is one of the oilseeds that have not yet been widely exploited as a source of protein for human consumption. High meat prices have prompted the food industry to produce nonmeat proteins. An important reason for the increased acceptance of vegetable proteins, such as texturized soy protein (TSP), is their low cost [7]. In addition to retexturing and restructuring vegetable food proteins, the extrusion cooking system performs several other important functions. Denaturation of protein lowers solubility, renders it digestible and destroys the biological activity of enzymes and toxic proteins [8].

Traditionally used oil extraction machinery in India results into poor oil extraction and oilseed cake contains substantial amount of residual oil. This oilseed cake which is generally used in animal feeds could be exploited for use in food products of the proper processing. Extrusion technology had a potential to process this large of byproducts. It may improve the property of oil, protein denaturation and texturization of along with starch gelatinization. Extrusion of flaxseed modifies texture and causes complex physicochemical changes. Under conditions of high temperature, high pressure and high shear force proteins were denatured, dietary fibre was broken down and cyanogenic glucoside was removed. Amino acid and soluble dietary fibre increased, fat and water content decreased, starch is gelatinized and degraded and the texture became loose and uniform [9].

The potential usefulness of plant protein concentrates depends on the versatility of their functional properties, which are influenced by several intrinsic factors, such as protein composition and conformation, as well as by environmental factors, such as the composition of the model system of food [10]. Functional properties affect processing applications, food quality, acceptance, and use in formulating food products [11]. The objective of the present study was to obtain a texturized protein from defatted flaxseed meal by extrusion, optimize the process using response surface methodology and evaluate the 
functional properties of the product produced.

\section{MATERIALS AND METHODS}

\subsection{Raw Material}

The flaxseed (LC 2063) used in this study was procured from Directorate of Seeds, Punjab Agricultural University, Ludhiana, India.

\subsection{Chemical Composition}

The moisture, fat, fiber, carbohydrates and protein content were determined [12].

\subsection{Oil Extraction}

The flaxseed was cleaned and defatted using laboratory oil expeller. The meal was dried and milled into grits using Super Mill (Perten Instruments, Sweeden). After that, the sample was sieved using 200 mesh screen to separate out the large particles of the seed coat.

\subsection{Extrusion Process for Flaxseed}

Texturization of flaxseed was carried out by using Clextral BC 21 twin screw extruder (Clextral, Firminy, France). RSM was used to optimize the texturization conditions. Operating condition of extruder were 14-17 per cent feed moisture, 300$500 \mathrm{rpm}$ screw speed and $120-180 \mathrm{oC}$ barrel temperature. Texturized samples were was milled into flour using cyclotec mill ( Newport Scientific, Australia) and packed in suitable packaging material for further study.

\subsection{Experimental Design}

Central composite design is generally used for experiments where zone of experimentation can be well defined through initial test runs. Extrusion process variables (feed moisture content, screw speed and temperature) were coded to the level of $-1,0,+1$ such that one factor at a time of experimental design was as follow [13].

\begin{tabular}{|l|c|c|c|c|c|}
\hline $\begin{array}{l}\text { Extrusion } \\
\text { parameters }\end{array}$ & -1.682 & -1 & 0 & +1 & +1.682 \\
\hline $\begin{array}{l}\text { Moisture } \\
\text { content (\%) }\end{array}$ & 11.954 & 14 & 17 & 20 & 22.046 \\
\hline $\begin{array}{l}\text { Screw } \\
\text { speed (rpm) }\end{array}$ & 231.800 & 300 & 400 & 500 & 568.200 \\
\hline $\begin{array}{l}\text { Barrel } \\
\text { temperature } \\
\left({ }^{\circ} \mathrm{C}\right)\end{array}$ & 99.54 & 120 & 150 & 180 & 200.460 \\
\hline
\end{tabular}

\subsection{Functional Properties}

\subsubsection{Water Absorption Index (WAI), Water}

Solubility Index (WSI) and Fat Absorption Capacity

(FAC)

Water absorption index (WAI) was measured [14]. First, 1g of protein flour was placed in a previously weighed $50 \mathrm{ml}$ centrifuge tube. Then, $10 \mathrm{ml}$ of distilled water was added and stirred homogeneously with a glass rod and centrifuged at $3000 \mathrm{rpm}$ for $10 \mathrm{~min}$ at room temperature $\left(22^{\circ} \mathrm{C}\right)$ using a Model T-8BL Laby ${ }^{\mathrm{TM}}$ centrifuge (Laby Laboratory Instruments, Ambala Cantt, India). The residue was weighed together with the centrifuge tube. The WAI values were expressed as gram of water absorbed/g of protein. The supernatant was transferred to previously weighed dish and put in hot air oven for evaporation of water. The residue was weighed. A similar method was used to measure fat absorption capacity (FAC), although a $0.5 \mathrm{~g}$ sample was used [15].

$$
\begin{aligned}
& \text { WAI }(\mathrm{g} / \mathrm{g})=\text { Weight of residue/ sample taken } \\
& \text { WSI (per cent) }=\frac{\text { Weight of dry matter in supernatant } \mathrm{x} 100}{\text { Dry weight of sample }} \\
& \text { FAC (per cent) }=\text { Weight of fat absorbed by sample } \mathrm{x} 100
\end{aligned}
$$

\subsubsection{Foaming Capacity}

One gram of protein flour was dissolved in $100 \mathrm{ml}$ of distilled water. Then the suspensions were whipped at a low speed in blender for $1 \mathrm{~min}$ at room temperature $\left(22^{\circ} \mathrm{C}\right)$ and poured into a $100 \mathrm{ml}$ cylinder. To determine foam stability (FS), foam volume was recorded $30 \mathrm{~min}$ after whipping and calculated [16].
FS $=$ Foam volume after $30 \mathrm{~min} /$ initial foam volume $\mathrm{x} 100$

\subsubsection{Water Holding Capacity (WHC)}

Five gram of protein flour was placed in a previously weighed $50 \mathrm{ml}$ centrifuge tube. Then, $10 \mathrm{ml}$ of distilled water was added and stirred homogeneously with a glass rod and centrifuged at $2000 \mathrm{rpm}$ for $10 \mathrm{~min}$ at room temperature $\left(22^{\circ} \mathrm{C}\right)$. The supernatant was decanted and the residue was 
weighed together with the centrifuge tube [12].

$$
\text { WHC }(\mathrm{ml} / \mathrm{g})=\frac{(\text { weight of tube }+ \text { sediment })-(\text { weight of tube }+5.0)}{5}
$$

\subsubsection{Bulk Density (BD)}

The Bulk densities $(\mathrm{g} / \mathrm{ml})$ of defatted flour were determined by volumetric method. The volume of the expanded sample was measured by using a $25 \mathrm{ml}$ graduated cylinder and gently tapped for 5 times. The volume of $10 \mathrm{~g}$ randomized samples was measured for each test. The ratio of sample weight and the replaced volume in the cylinder was calculated as bulk density (w/v) [17].

$$
\text { Bulk density }(\mathrm{g} / \mathrm{ml})=\frac{\text { Weight of sample }}{\text { Volume displaced by sample }}
$$

\section{RESULTS AND DISCUSSION}

\subsection{Chemical Composition}

The moisture, fat, fibre and protein content were 2.61 per cent, 2.707 per cent, 12.24 per cent, and 38.24 per cent, respectively.

\subsection{Functional Properties}

\subsubsection{Fat Absorption Capacity}

The quadratic model obtained from regression analysis for fat absorption capacity (FAC) in terms of coded levels of the variables was developed as follows.

$\mathrm{FAC}=+73.08+4.84 \times \mathrm{A}-0.43 \times \mathrm{B}-0.31 \times \mathrm{C}-2.90 \times \mathrm{A} \times \mathrm{B}-$ $1.59 \times \mathrm{A} \times \mathrm{C}-2.42 \times \mathrm{B} \times \mathrm{C}+3.54 \times \mathrm{A}^{2}+0.74 \times \mathrm{B}^{2}+5.39 \times \mathrm{C}^{2}$

The analysis of variance (ANOVA) for FAC of quadratic model is given in Table 3. There was only a 0.01 per cent chance that a Model F-Value this large could occur due to noise. If there are many insignificant model terms, model reduction might improve model. Non-significant lack of fit was good for the model to fit.

The P-value for Lack of fit 0.30 implies that it was not significant. The value of $\mathrm{R}^{2}$ was found to be 0.99 . Regression analysis results (Table 3) showed the significant positive linear influence of moisture, while negative influence of screw speed and temperature $(\mathrm{P}<0.05)$ was recorded. There was significant quadratic terms effects $(\mathrm{P}<0.01)$ of moisture content and temperature on FAC. There was also reported significant interaction of feed moisture with screw speed, feed moisture with temperature and screw speed with temperature $(\mathrm{P}<0.01)$ on FAC. The FAC varied from 71.07 to 91.48 per cent protein flour (Table 1). It was observed from regressions analysis that during extrusion-cooking, higher moisture contents increase FAC of protein flour (Fig. 1a). The increase in FAC with increasing screw speed was consistent. Defatting increases the protein solubility and water and oil absorption capacities of the meals. The capacity of protein to absorb water and oil is determined by its polar and non polar amino acids composition, respectively [18]. FAC of the flaxseed protein concentrate was higher than that of amaranth protein concentrate [19].

\subsubsection{Water Holding Capacity}

Water holding capacity is the ability to retain water against gravity, and includes bound water, hydrodynamic water, capillary water and physically entrapped water [20]. The quadratic model obtained from regression analysis for water holding capacity (WHC) in terms of coded levels of the variables was developed as follows.

$$
\begin{gathered}
\mathrm{WHC}=+1.41+0.30 \times \mathrm{A}-0.35 \times \mathrm{B}-0.48 \times \mathrm{C}-0.094 \times \mathrm{A} \times \mathrm{B}- \\
0.051 \times \mathrm{A} \times \mathrm{C}+0.30 \times \mathrm{B} \times \mathrm{C}+0.62 \times \mathrm{A}^{2}-0.13 \times \mathrm{B}^{2}+0.21 \times \mathrm{C}^{2}
\end{gathered}
$$

The Model F-value of 56.19 implies that model was significant. In this case $\mathrm{A}, \mathrm{B}, \mathrm{C}, \mathrm{BC}, \mathrm{A}^{2}, \mathrm{~B}^{2}, \mathrm{C}^{2}$ are significant model terms. Non significant lack of fit was good for the model to fit. Model ratio of 28.25 indicates an adequate signal. This model could be used to navigate the design space. The P-value for Lack of fit 0.67 implies that it was not significant. The value of $\mathrm{R}^{2}$ was found to be 0.98 . The analysis of variance (ANOVA) for WHC of quadratic model is given in Table 3. Regression analysis results showed that the significant positive linear influence of moisture, while negative influence of screw speed and temperature $(\mathrm{P}<0.05)$ was recorded. There was significant quadratic terms effect $(\mathrm{P}<0.01)$ of moisture content, screw speed and temperature on WHC. There was also reported significant interaction of screw speed with barrel temperature $(\mathrm{P}<0.01)$ on WHC. The WHC varied from 0.469 to $3.501 \mathrm{ml} / \mathrm{g}$ protein flour (Table 1). It was observed from regressions analysis that during extrusioncooking, higher moisture contents increase WHC of protein flour (Fig. 2a). Water holding capacity of protein is very important as it affects the texture, juiciness, and taste of food products. The capacity of protein to absorb water was determined by its polar and non polar amino acids composition [18]. The amount of water associated to proteins is closely related with its amino acids profile and increases with the number of charged residues, [21] conformation, hydrophobicity, $\mathrm{pH}$, temperature, ionic strength and protein concentration [22]. 


\subsubsection{Water Solubility Index}

WSI, often used as an indicator of degradation of molecular components [23]. WSI measures the amount of soluble components released from the protein and other molecules after extrusion. High WSI is an in vitro indicator of good digestibility [24]. The quadratic model obtained from regression analysis for water solubility index (WSI) in terms of coded levels of the variables was developed as follows.

$$
\begin{aligned}
& \mathrm{WSI}=+4.20+0.58 \times \mathrm{A}-0.17 \times \mathrm{B}-1.38 \times \mathrm{C}-0.43 \times \mathrm{A} \times \mathrm{B}- \\
& 0.57 \times \mathrm{A} \times \mathrm{C}+0.27 \times \mathrm{B} \times \mathrm{C}-0.38 \times \mathrm{A}^{2}-0.77 \times \mathrm{B}^{2}-0.30 \times \mathrm{C}^{2}
\end{aligned}
$$

Regression model fitted to experimental results. The P-value for Lack of fit 0.12 implies that it was significant. The value of $\mathrm{R}^{2}$ was found to be 0.96 . Regression analysis results showed the significant positive linear influence of moisture, while negative influence of screw speed and temperature $(\mathrm{P}<0.05)$ was recorded. There was significant quadratic terms effect $(\mathrm{P}<0.01)$ of moisture content and temperature on WSI. There was also significant interaction of moisture and temperature $(\mathrm{P}<0.01)$ on WSI. The WSI varied from 0.70 to 6.35 per cent protein flour (Table 1). It was observed from regressions analysis that during extrusion-cooking, higher moisture contents increase WSI of protein flour (Fig. 3a). The high mechanical shear caused breakdown of macromolecules to small molecules with higher solubility. The increase in WSI with increasing screw speed was consistent with the results reported by other researchers [25]. Also increasing temperature would result in degradation of molecule resulting in an increase in WSI [26].

\subsubsection{Water Absorption Index}

High WAI is an in vitro indicator of good digestibility of protein starch and other molecules [24]. The WAI measures the amount of water absorbed by starch and can be used as an index of gelatinization [27]. WAI depends on the availability of hydrophilic groups that bind water molecules. The quadratic model obtained from regression analysis for water absorption index in terms of coded levels of the variables was developed as fallows.

$$
\begin{aligned}
& \mathrm{WAI}=+2.35+0.13 \times \mathrm{A}-0.35 \times \mathrm{B}-0.65 \times \mathrm{C}-0.12 \times \mathrm{A} \times \mathrm{B}+ \\
& 0.098 \times \mathrm{A} \times \mathrm{C}+0.65 \times \mathrm{B} \times \mathrm{C}+0.60 \times \mathrm{A}^{2}-0.18 \times \mathrm{B}^{2}+ \\
& 0.31 \times \mathrm{C}^{2}
\end{aligned}
$$

The P-value for Lack of fit 0.48 implies that it was not significant. The value of $\mathrm{R}^{2}$ is found to be 0.93 . Regression analysis results showed that screw speed and temperature had significant negative and moisture had positive linear $(\mathrm{P}<0.001)$ effect and significant quadratic effect on WAI. Interaction of screw speed with temperature had significant influence $(\mathrm{P}<0.01)$. The WAI of protein flour ranges from
1.35 to $4.85 \mathrm{~g} / \mathrm{g}$ (Table 1 ). Increases in moisture content reduce the water absorption index. Moisture content, acting as a plasticizer during extrusion cooking, reduces the degradation of starch granules, this result in an increased capacity for water absorption [28]. WAI was higher for lower screw speed and lower temperature as shown in response surface plot (Fig. $4 \mathrm{~b}$ and $4 \mathrm{c}$ ). It could be expected that more undamaged polymer chains and a greater availability of hydrophilic groups, which could bind more water resulted in higher values of WAI under low shear conditions with lower screw speed [29].

\subsubsection{Bulk Density}

Bulk density is a very important parameter in the production of texturized products. Density is a measure of how much expansion has occurred as a result of extrusion. The heat developed during extrusion can increase the temperature of the moisture above the boiling point so that when the extrudate exits from the die, a part of the moisture would quickly flash off as steam and result in an expanded structure with large alveoli and low density. The quadratic model obtained from regression analysis for bulk density (BD) in terms of coded levels of the variables was developed as follows.

Bulk Density $=+0.23+0.011 \times \mathrm{A}-0.00288 \times \mathrm{B}-0.00287 \times \mathrm{C}$
$+0.00136 \times \mathrm{A} \times \mathrm{B}-0.021 \times \mathrm{A} \times \mathrm{C}+0.015 \times \mathrm{B} \times \mathrm{C}$
$+0.043 \times \mathrm{A}^{2}+0.020 \times \mathrm{B}^{2}-0.015 \times \mathrm{C}^{2}$

The analysis of variance (ANOVA) for bulk density of quadratic model is given in Table 3. Regression model fitted to experimental results of bulk density showed The P-value for Lack of fit 0.57 implies that it was not significant. The value of $\mathrm{R}^{2}$ is found to be 0.97 . The bulk density of protein flour ranges from 0.189 to $0.359 \mathrm{~g} / \mathrm{ml}$ (Table 1). Regression analyses indicate that bulk density decreases with decrease in moisture (Fig. 5a).The high dependence of bulk density and expansion on feed moisture would reflect its influence on elasticity characteristics of the starch- based material. Increased feed moisture content during extrusion may reduce the elasticity of the material through plasticization of the melt, resulting in reduced SME and lower bulk density was observed at high screw speed and decreasing the expansion and increasing the density of extrudate. Bulk density low at high screw speed (Fig. 5b). Bulk density increased with decrease in moisture as higher water content produced extrudates denser than those produced with low water content. Similar results were reported [30] in study of effect of extrusion condition on the soya rice extrudates and effect of extrusion variables on waxy hull less barley [31].

\subsubsection{Foaming Capacity}

Foams were gaseous droplets encapsulated by a liquid film containing soluble surfactant protein resulting in reduced interfacial tension between gas and water. The quadratic 
model obtained from regression analysis for foaming capacity (FC) in terms of coded levels of the variables was developed as follows.

Foaming Capacity $=+17.25 \quad+0.00805 \times \mathrm{A} \quad-1.84 \times \mathrm{B}$ $-0.73 \times \mathrm{C}-1.32 \times \mathrm{A} \times \mathrm{B}+0.33 \times \mathrm{A} \times \mathrm{C}+0.39 \times \mathrm{B} \times \mathrm{C}-2.74 \times \mathrm{A}^{2}$ $1.36 \times \mathrm{B}^{2}-1.45 \times \mathrm{C}^{2}$

The analysis of variance (ANOVA) for foaming capacity of quadratic model is given in Table 3. Regression model fitted to experimental results of foaming capacity showed. The Pvalue for Lack of fit 0.42 implies that it was not significant. The value of $\mathrm{R}^{2}$ is found to be 0.99 . Interaction $(\mathrm{P}<0.05)$ of all independent variables were found significant. The foaming capacity of protein flour ranges from 9.23 to 17.81 percent (Table 1). Regression analyses indicate that foaming capacity decreases with decrease in moisture (Fig. 6a). Foaming capacity was low at high screw speed (Fig. 6b).

\section{CONCLUSIONS}

There was also reported significant interaction of feed moisture with screw speed, feed moisture with temperature and screw speed with temperature on FAC. The increase in FAC with increasing screw speed was consistent. Defatting increases the protein solubility and water and oil absorption capacities of the meals. Significant positive linear influence of feed moisture, while negative influence of screw speed and temperature on WHC was recorded. Screw speed with temperature had significant interaction on WHC. Feed moisture had positive effect, while screw speed and temperature had negative effect on WSI was recorded. There was also reported significant interaction of moisture and temperature $(\mathrm{P}<0.01)$ on WSI. Higher moisture contents increased WSI of protein flour during extrusion. Screw speed and temperature had significant negative and moisture had positive linear effect and significant quadratic effect on WAI. Interaction of screw speed with temperature had significant influence. Bulk density decreases with decrease in moisture. Foaming capacity decreases with decrease in moisture. Foaming capacity was low at high screw speed.

\section{REFERENCES}

[1] Hagan RO, Dhal SR, Villota R (1986) Texturization of co precipitated soybean and peanut protein by twin screw extrusion. J Food Sci 51:367.

[2] Bhat R, Karim AA (2009) Exploring the nutritional potential of wild and underutilized legumes. Comp Rev Food Sci Food Safety 8:305-331.

[3] Boye J, Zare F, Pletch A (2010) Pulse proteins: Processing, characterization, functional properties and applications in food and feed. Food Res Intl 43:414431.

[4] Salcedo-Chávez B, Osuna-Castro JA, Guevara-Lara F, Domínguez-Domínguez J, Paredes-López O (2002)
Optimization of the isoelectric precipitation method to obtain protein isolates from amaranth (Amaranthus cruentus) seeds. J Agric Food Chem 50: 6515-6520.

[5] Shils ME, Olson JA, Shike M, Ross AC (2002) Nutrición en salud y enfermedad, Volumen II 9 A edition, McGrawHill Interamericana Editores, S.A. de C.V. México, D.F. 1103-133.

[6] Payne TJ (2000) Promoting better health with flaxseed in bread. Cereal Foods World 45:102-104.

[7] Singh P, Kumar R, Sabapathy SN, Bawa AS (2008) Functional and edible uses of soy protein products. Comp Rev Food Sci Food Safety 7:14-28.

[8] Altschul A M (1965) In proteins: Their chemistry and politics. Basic Books. New York.

[9] Li-Ci-Li, Miao-Ming (2007) Influence of extrusion on chemical components and texture of flaxseed meal. Food Sci Tech 10:77-80.

[10] Fernández-Quintela A, Macarulla MT, Barrio AS, Martínez JA (1997) Composition and functional properties of protein isolates obtained from commercial legumes grown in northern Spain. Plant foods Human Nut 51:331-342.

[11] Mahajan A, Dua S (2002) Salts and pH induced changes in functional properties of amaranth (Amaranthus tricolor L.) seed meal. Cereal chem 79:834-837.

[12] AOAC (2000) Official methods of Analysis.Association of Official Analytical Chemists, Guthersburg, Maryland, USA. $17^{\text {th }}$ edition.

[13] Myers RH (1971) Response surface methodology. $1^{\text {st }}$ edition. Boston, Mass: Allyn and Bacon, 247.

[14] Stojceska V, Ainsworth P, Plunkett A, Ibanoglu S (2009) The effect of extrusion cooking using different water feed rates on the quality of ready-to-eat snacks made from food by-products. Food Chem 114:226-232.

[15] Lin MJY, Humbert ES, Sosulski FW (1974) Functional properties of sunflower meal product. J Food Sci 39:368-370.

[16] Kabirullah M, Wills RBH (1983) Characterization of sunflower protein. J Agri Food Chem 31:953-956.

[17] Pan Z, Zhang S, Jane J (1998) Effects of extrusion variables and chemicals on the properties of starchbased binders and processing conditions. Cereal chem 75:541-546.

[18] Sathe SK, Salunkhe DK (1981) Functional properties of the great Northern bean proteins: emulsion, foaming, viscosity, and gelation properties. J Food Sci 46:71-81.

[19] De Luquez N, Fernandez S, Arellano M, Mucciarelli S (1997) Concentrado proteico de Amaranthus mantegazzianus: Caracterización físico-químicobiológica. Archivos Latinoamericanos de Nutrición 47:359-361.

[20] Moure A, Sineiro J, Domınguez H, Parajo JC (2006) Functionality of oilseed protein products: A review. Food Res Intl 39:945-963. 
[21] Kuntz ID Jr, Kauzmann W (1974) Hydration of proteins and polypeptides. Adv protein Chem 28:239345.

[22] Damodaran S (1997) Food prtiens: An overview. In: S. Damodaran and A. Paraf (Eds), Food prtiens and their application New York: Marcel Dekker.

[23] Kirby AR, Ollett AL, Parker R, Smith AC (1988) An experimental study of screw configuration effects in the twin-screw extrusion-cooking of maize grits. $\mathrm{J}$ Food Engg 8: 247-272.

[24] Guha M, Ali SZ and Bhattacharya S (1997) Twin-screw extrusion of rice flour without a die: Effect of barrel temperature and screw speed on extrusion and extrudate characteristics. J Food Engg 32:251-267.

[25] Dogan H, Karwe MV (2003) Physicochemical properties of quinoa extrudates. Food Sci Technol Int Madrid 9:101-114.

[26] Ding QB, Ainsworth P, Tucker G, Marson H (2005) The effect of extrusion conditions on the physicochemical properties and sensory characteristics of rice based expanded snacks. J Food Engg 66:283-289.

[27] Anderson RA, Conway HF, Griffin EL (1969) Gelatinization of corn grits by roll and extrusion cooking. Cereal Sci Today 14:4-12.

[28] Hagenimana A, Ding X, Fang T (2006) Evaluation of rice flour modified by extrusion cooking. J Cereal Sci 43:38-46.

[29] Jin Z, Hsieh F, Huff HE (1995) Effects of soy fiber, salt, sugar, and screw speed on physical properties and microstructure of cornmeal extrudate. J Cereal Sci 22:185-194.

[30] Patil RT, Singh DS, Tribelhorn RE (1990) Effect of Processing Conditions on Extrusion Cooking of SoyRice Blend with a Dry Extrusion Cooker. J Food Sci Technol 27: 376-378.

[31] Koksel H, Ryu G H, Basman A and Demiralp H (2004) Effects of extrusion variables on the properties of waxy hulless barley extrudates. Nahrung Food 48:19-24.

Table 1: Effect of Extrusion condition on product responses $(n=3)$

\begin{tabular}{|c|c|c|c|c|c|c|c|c|}
\hline \multicolumn{3}{|c|}{ Extrusion conditions } & \multicolumn{6}{|c|}{ Responses } \\
\hline $\begin{array}{c}\text { Moisture } \\
\text { content } \\
(\%)\end{array}$ & $\begin{array}{l}\text { Screw } \\
\text { speed } \\
(\mathrm{rpm})\end{array}$ & $\begin{array}{c}\text { Temperature } \\
\left({ }^{0} \mathrm{C}\right)\end{array}$ & $\begin{array}{c}\text { FAC } \\
(\%)\end{array}$ & $\begin{array}{l}\text { WHC } \\
(\mathrm{ml} / \mathrm{g})\end{array}$ & $\begin{array}{l}\text { WSI } \\
(\%)\end{array}$ & $\begin{array}{l}\text { WAI } \\
(\mathrm{g} / \mathrm{g})\end{array}$ & $\begin{array}{c}\mathrm{BD} \\
(\mathrm{g} / \mathrm{ml})\end{array}$ & $\begin{array}{l}\mathrm{FC} \\
(\%)\end{array}$ \\
\hline 14 & 300 & 120 & 71.07 & 2.85 & 3.07 & 4.72 & 0.2549 & 13.86 \\
\hline 20 & 300 & 120 & 90.21 & 3.5905 & 6.36 & 4.85 & 0.339 & 15.8 \\
\hline 14 & 500 & 120 & 81.47 & 1.6 & 2.6 & 3.07 & 0.229 & 12 \\
\hline 20 & 500 & 120 & 88.41 & 2.14 & 4.16 & 2.45 & 0.293 & 8.97 \\
\hline 14 & 300 & 180 & 79.29 & 1.41 & 0.83 & 1.89 & 0.269 & 10.61 \\
\hline 20 & 300 & 180 & 91.48 & 2.12 & 1.79 & 2.13 & 0.243 & 14.17 \\
\hline 14 & 500 & 180 & 79.44 & 1.55 & 1.41 & 2.55 & 0.279 & 10.61 \\
\hline 20 & 500 & 180 & 80.6 & 1.71 & 0.7 & 2.6 & 0.284 & 8.62 \\
\hline 17 & 400 & 150 & 73.6 & 1.33 & 4.16 & 2.838 & 0.24 & 17.12 \\
\hline 17 & 400 & 150 & 73.11 & 1.47 & 3.78 & 2.8 & 0.216 & 17.81 \\
\hline 17 & 400 & 150 & 73.25 & 1.21 & 4.52 & 2.075 & 0.24 & 17 \\
\hline 17 & 400 & 150 & 73.61 & 1.73 & 4.15 & 2.085 & 0.219 & 17 \\
\hline 17 & 400 & 150 & 72.55 & 1.34 & 4.55 & 2.21 & 0.25 & 17.5 \\
\hline 17 & 400 & 150 & 72.38 & 1.369 & 3.95 & 2.091 & 0.21 & 17.15 \\
\hline 11.95 & 400 & 150 & 75.2 & 2.537 & 2.47 & 3.537 & 0.349 & 9.45 \\
\hline 22.05 & 400 & 150 & 91.02 & 3.71 & 4.12 & 4.7 & 0.359 & 9.23 \\
\hline 17 & 231.8 & 150 & 76.29 & 1.55 & 1.94 & 2.495 & 0.294 & 16.5 \\
\hline 17 & 568.2 & 150 & 74.08 & 0.469 & 2.43 & 1.35 & 0.283 & 10 \\
\hline 17 & 400 & 99.54 & 89.5 & 2.91 & 5.75 & 4.21 & 0.189 & 14 \\
\hline 17 & 400 & 200.46 & 87.21 & 1.06 & 1.33 & 2.429 & 0.19 & 12 \\
\hline
\end{tabular}


Table 2: Chemical composition of flaxseed defatted cake

\begin{tabular}{|l|c|c|}
\hline Parameter & Mean & \pm SD \\
\hline Moisture content (\%) & 2.610 & 0.197 \\
\hline Protein (\%) & 38.143 & 0.495 \\
\hline Fat (\%) & 2.707 & 0.020 \\
\hline Fibre (\%) & 12.240 & 0.075 \\
\hline
\end{tabular}

Table 3: Significance on Coefficient estimate

\begin{tabular}{|c|c|c|c|c|c|c|}
\hline Factors & FAC & WHC & WSI & WAI & $\mathrm{BD}$ & $\mathrm{FC}$ \\
\hline Intercept of Model & 73.08 & 1.41 & 4.20 & 2.35 & 0.23 & 17.250 \\
\hline A: Moisture content & 4.84 & 0.30 & 0.58 & 0.13 & 0.011 & 0.0081 \\
\hline B: Screw speed & -0.43 & -0.35 & -0.17 & -0.35 & -0.0029 & -1.8400 \\
\hline C: Barrel temperature & -0.31 & -0.48 & -1.38 & -0.65 & -0.0028 & -0.7300 \\
\hline AB (Moisture content x Screw speed) & -2.90 & -0.094 & -0.43 & -0.12 & -0.0014 & -1.3200 \\
\hline AC (Moisture content $x$ Barrel temperature) & -1.59 & -0.051 & -0.57 & 0.098 & -0.0210 & 0.3300 \\
\hline BC (Screw speed $x$ Barrel temperature) & -2.42 & 0.30 & 0.27 & 0.65 & 0.0150 & 0.3900 \\
\hline $\mathrm{A}^{2}{\text { (Moisture content })^{2}}^{2}$ & 3.54 & 0.62 & -0.38 & 0.60 & 0.0430 & -2.7400 \\
\hline $\mathrm{B}^{2}(\text { Screw speed })^{2}$ & 0.74 & -0.13 & -0.77 & -0.18 & 0.0200 & -1.3600 \\
\hline $\mathrm{C}^{2}{\text { (Barrel temperature })^{2}}^{2}$ & 5.39 & 0.21 & -0.30 & 0.31 & -0.0150 & -1.4500 \\
\hline P-Value for lack of fit & 0.30 & 0.67 & 0.12 & 0.48 & 0.57 & 0.42 \\
\hline $\mathrm{R}^{2}$ & 0.99 & 0.98 & 0.96 & 0.93 & 0.97 & 0.99 \\
\hline
\end{tabular}

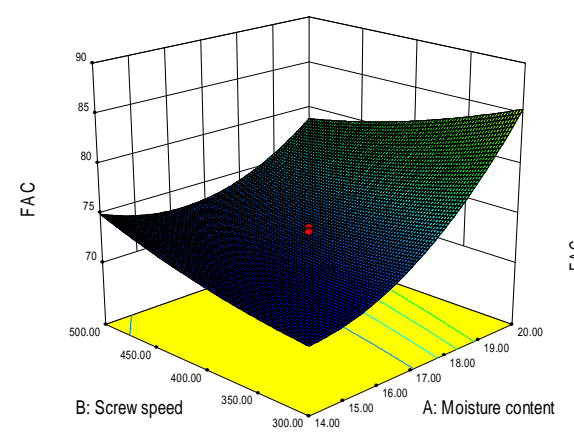

a

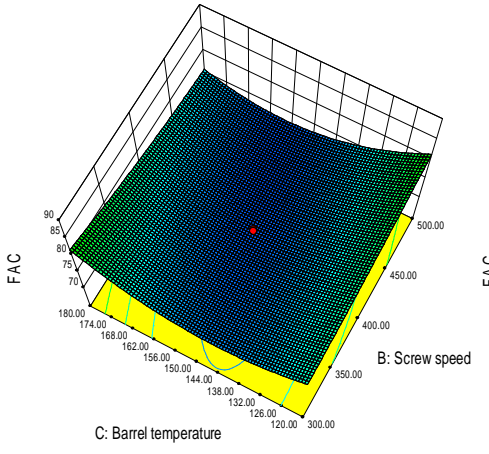

b

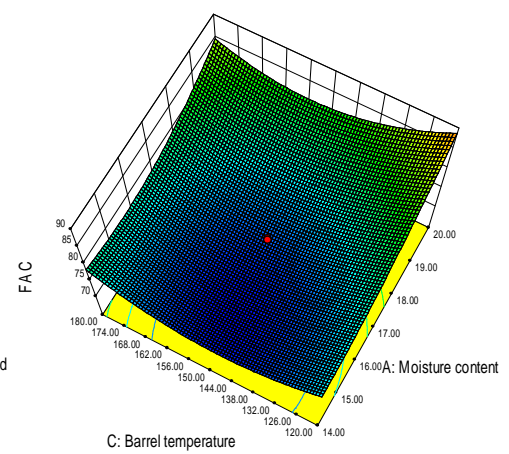

c

Fig. 1: The effect of Moisture, Screw speed and Temperature on FAC (fat absorption capacity) 


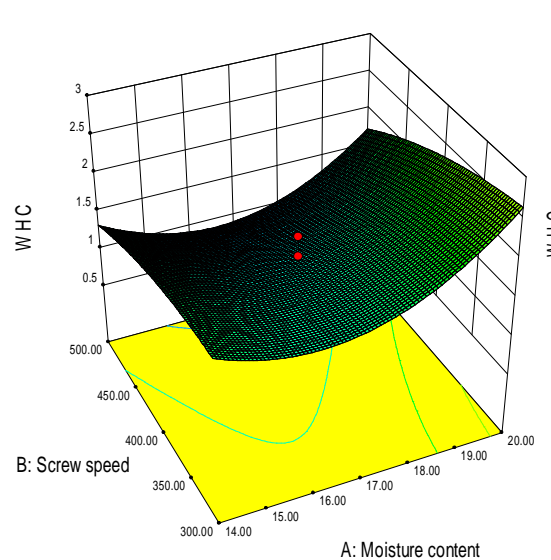

a

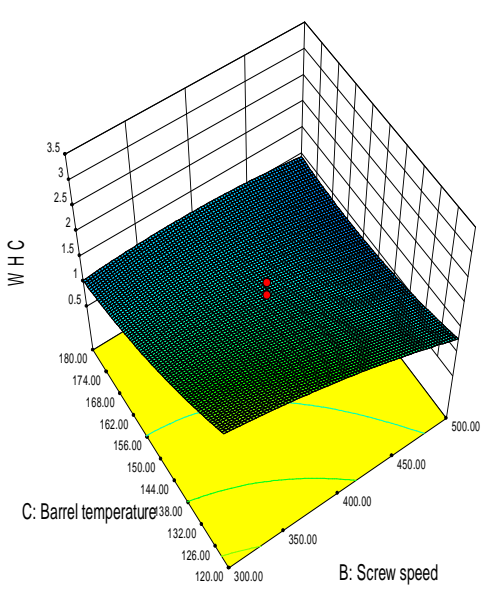

$\mathrm{b}$

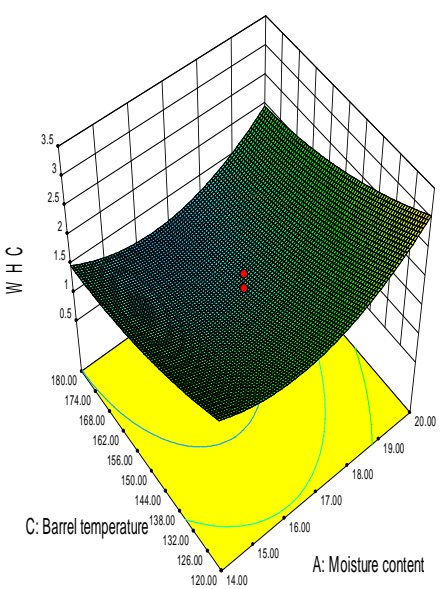

$\mathrm{c}$

Fig. 2: The effect of Moisture, Screw speed and Temperature on WHC (water holding capacity)

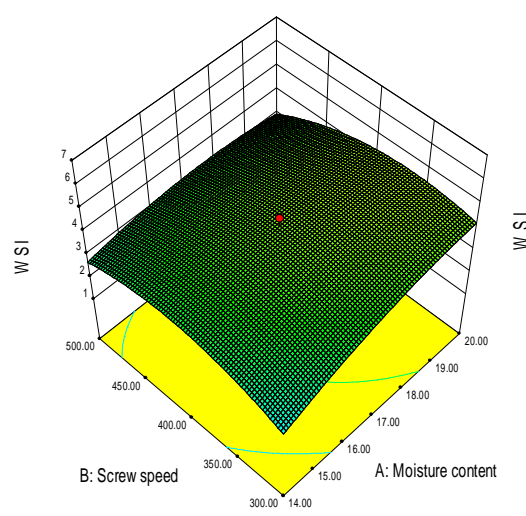

a

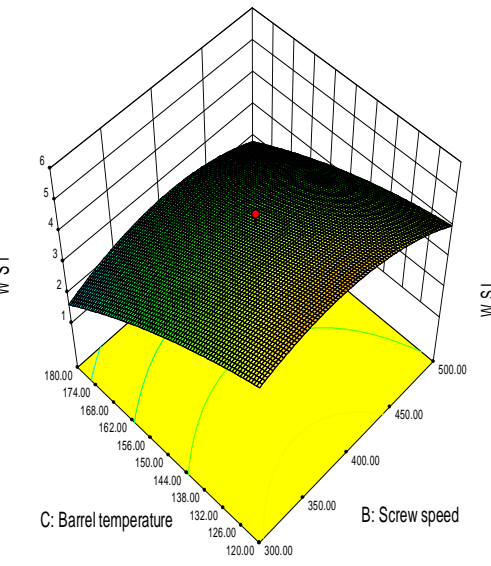

b

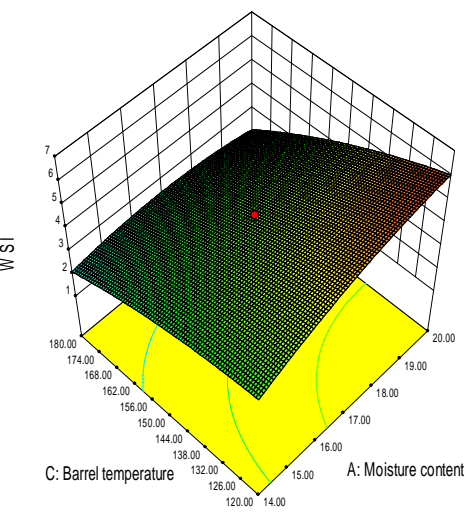

c

Fig. 3: The effect of Moisture, Screw speed and Temperature on WSI (water solubility index)

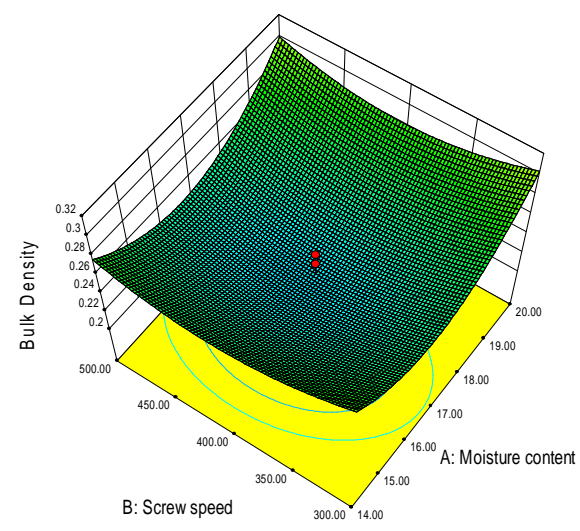

a
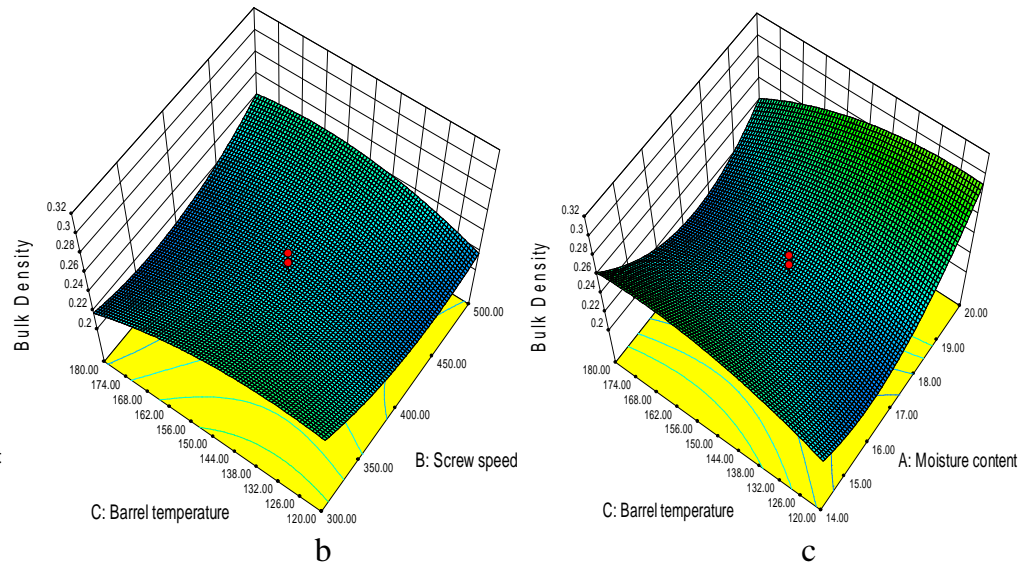

Fig. 4: The effect of Moisture, Screw speed and Temperature on WAI (water absorption index) 


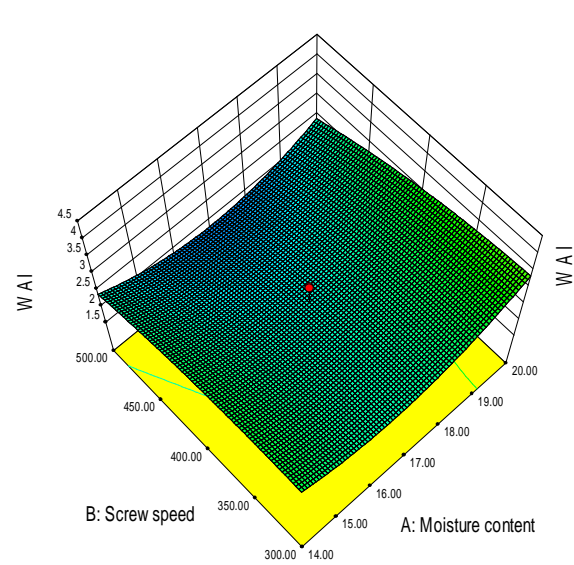

a

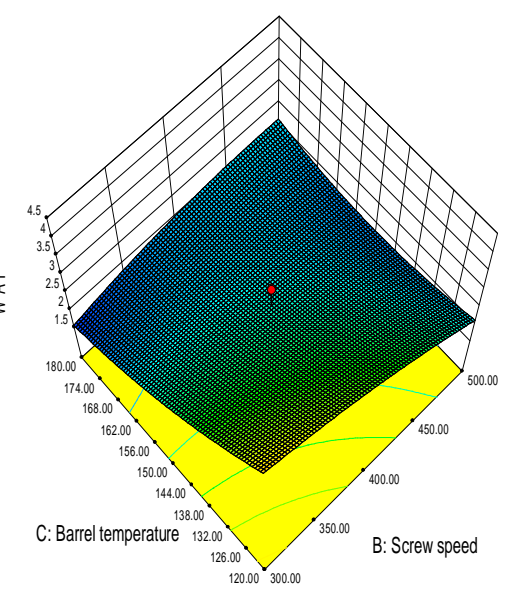

b

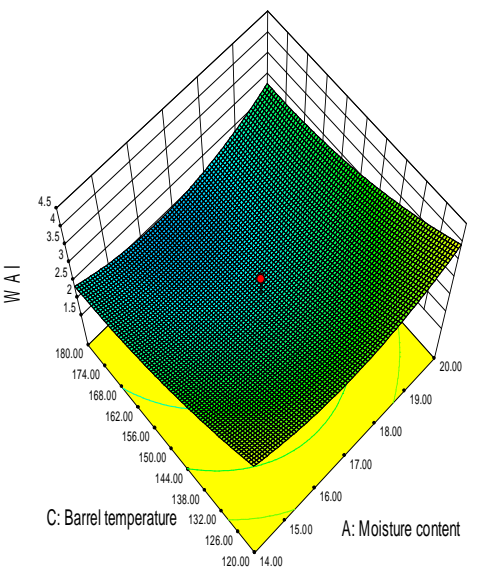

Fig. 5: The effect of Moisture, Screw speed and Temperature on BD (bulk density)

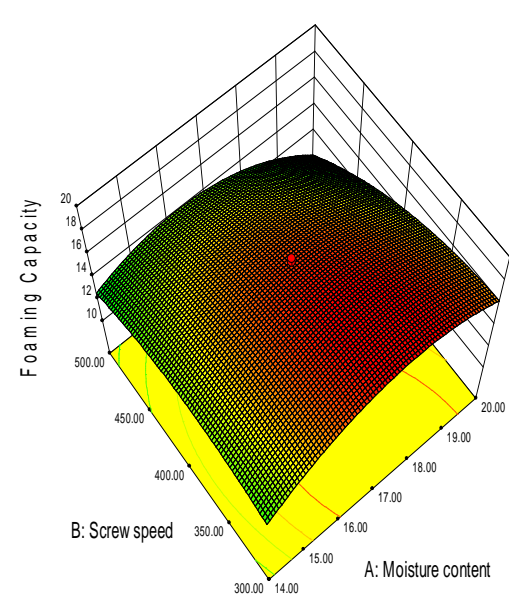

a

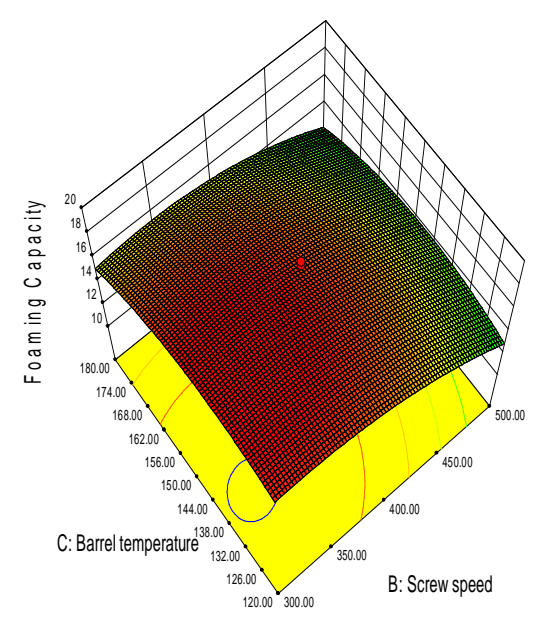

b

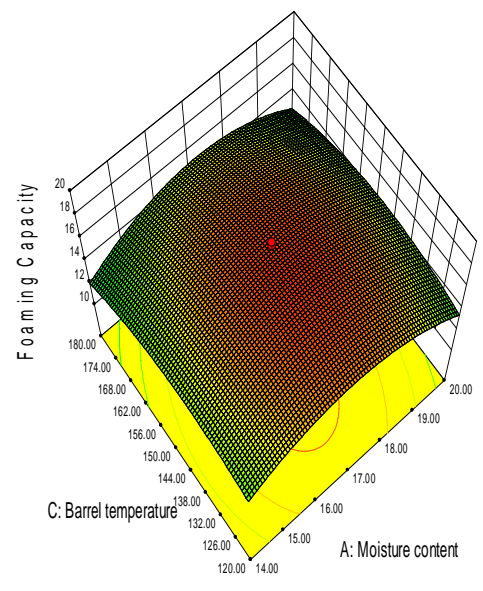

C

Fig. 6: The effect of Moisture, Screw speed and Temperature on FC (Foaming capacity) 